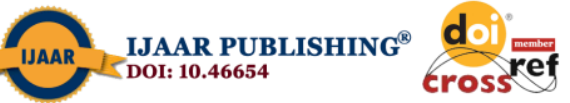

International Journal of Advanced Academic Research (Social and Management Sciences) | ISSN: 2488-9849

Vol. 6, Issue 12 (December, 2020) | www.ijaar.org

Journal DOI: 10.46654/ij.24889849

Article DOI: 10.46654/ij.24889849.s61254

\title{
AN APPRAISAL OF RUSSIA AND UNITED STATES (US) INVOLVEMENT IN SYRIA CIVIL WAR
}

\author{
Ijeoma Patience Ebohwoke \\ Department of Political Science, \\ Nnamdi Azikiwe University, Awka, Nigeria \\ ebohwokeijeoma@gmail.com \\ Prof. Eze Raphael C. \\ Department of Political Science, \\ Nnamdi Azikiwe University, Awka, Nigeria \\ ezeraphaelc@yahoo.com
}

\begin{abstract}
Concerned by the worst humanitarian intractable civil war in Syria, this paper aims to appraise the involvements of Russia and the US inthewar. It questions the reasons behind these involvements as well as the implications of their respective involvements. To this end, the study adopted the theory of political realism (power model) as its framework of analysis. Utilizing documentary sources of data collection, the research employed the content analysis technique to analyze data collected. Through logical chain of evidence, deductions and inferences, the study discovered that although the driving force behind Russia and US involvements in Syria civil war is centered on their desire to secure and advance respective national interests, the resurgence of Russia as a formidable challenger in the Middle East is diminishing US hegemony in the region and US reluctance to accept this new reality will continue to cripple Syria and the region at large. Based on these findings, the paper concludes that, unless there emerges a ground for compromise, or a clear dominant power, or an internationally recognized efficient bureaucracy, the unrest in Syria will drag on.
\end{abstract}

Keywords: Arab Spring, National Interests, Superpowers Involvement. 


\section{INTRODUCTION}

In 2011, the Middle East and some parts of North America witnessed an unprecedented phenomenon known as the Arab spring. Waves of revolutionary disruption occurred across major cities where demands for freedom, transparency and democracy were chanted by the public. The protest which began in Tunisia were incited by the self-immolation of Mohammed Bouazizi in December 2010. The success of Tunisia's revolution ignited rapid progression of similar actions in countries such as Egypt, Yemen, Libya, morocco, Syria and a host of others. Although the demands of these various nationals were similar in each country, the outcome was quite different. In Syria, the protestors were initially small in number and only demanded political reform from their government but the protest took an unexpected turn when some teenagers in Deraa were arrested and brutally manhandled by Assad's security forces for painting revolutionary slogan on their school wall (Emadi, 2011). What began as a peaceful protest against an authoritarian regime, mushroomed into a full blown civil war. The Syria civil war now has covert and overt involvements of multiple countries, but the focus of this study rests on Russia and US Involvement because of their super power positions in international community hierarchy. While Russia and the US are particular about ending the sectarian aspect of the war, their actions however, indicate which of the two sides they support.

\section{PROBLEM STATEMENT}

Since the early 1990s, the connotation and scope of the United Nations nonintervention principles, have constantly been breached by the emanation of various norms and practices, designed to protect civilian rights and counter terrorism. In the face of competing powers for national interests, state sovereignty continues to be more abstract than ever. Since the end of WWII, the proliferation of super powers involvements in the domestic affairs of warring states is indeed a quandary, as the implications of these involvements becomemore conspicuous than ever. According to Patrick Regan (2000) in his book titled; Civil Wars and Foreign Powers, he posits that out of about 100 civil wars fought between 1944-1999, roughly two third of these wars have witnessed the involvements of foreign powers. More prominent is the numerous situations in which superpowers continue to take the lead in these involvements. For example, the US has been involved in almosthalfof these wars (Regan, 2000). There are many controversies about foreign involvements in civil wars particularly with respect to its role in the betterment of the warring state. For Regan (2002), although there have been about $30 \%$ success rate of the total number of foreign involvements in civil wars, unsolicited involvements usually protract the duration of the war leading to increased loss of lives and properties, internal and external refugee crisis, crippled economy, increased crime rates and in most cases, some of these countries take years to regain stability while others never recover. Syria as a case study in its numerous years of civil unrest has been ranked by Aljazeera news as the worst humanitarian crisis since the 2011 Arab Spring because of all its catastrophic attributes. Therefore, the outcome of the Syria civil war puts a question mark on Russia and US involvements in it. Why is Russia and US involved in Syria? Has their involvement helped or worsened the situation in Syria? 


\section{CONCEPTUALIZING NATIONAL INTERESTS AND SUPER POWERS INVOLVEMENTS IN CIVIL WARS}

\section{NATIONAL INTEREST}

Hans Morgenthau's attempt to describe national interests in the face of global power politics argues that, because the survival of nations is the focal point of national interest around which other decisions are made to fit according to emerging circumstances, therefore, the concept of national interest connotes neither a peaceful and harmonious world nor the avoidance of war in its pursuit but rather, it assumes continuous threat of war and conflict that can be minimized through continuous adjustment and readjustment of conflicting interests by dialogue and other diplomatic means (Morgenthau, 1948). Looking at the balance of power as national interest, Hans Morgenthau posits that the balance of power is the universal law of international power politics and has been the guiding principles of US foreign policy. In line with the following, this paper sees national interests as the pursuit by all means, those things that ensure survival, add value, prestige and power to the existence of a state.

\section{SUPER POWERS INVOLVEMENT}

The Center for The Study of Civil War (CSCW, 2010) defines super powers as transnational factors that possess the capability to play an important role in the escalation and dynamics of conflict once underway. They also play a significant role in the resolution or protraction of such conflict. David (2013) inter-alia described super powers as having the ability to unilaterally block settlement of civil war. If the state cannot block any kind of political settlement like Russia and US continues to do in the United Nations Security Council, then they cannot be considered super powers. For CSCW, the genre of super powers involvements leads to little, if any improvement and all too often to the trajectory of sustainable development (CSCW, 2010). Arguing along these lines, Regan declares that involvement on behalf of the government has been more successful than that which is done on behalf of the opposition party. He further argues that success is most likely only when such involvement is done multilaterally under the UN auspices and when the peace keeping force is unbiased and invited by both parties (Regan, 2002).

\section{PAPER FOCUS}

This paper is set to appraise the motives behind Russia and US involvement in Syria civil war with the intent to proffering necessary panacea to ending the catastrophic war. To this end, the following questions were raised to guide the study:

(a) Why is Russia and US involved in Syria civil war?

(b) What are the implications of their respective involvement in Syria civil war?

Taking cognizance of these research questions, two hypotheses were formulated;

I. Russia and US involvement in Syria were prompted by the desire to secure and advance their respective national interests.

II. The protraction of the war emanating from failed political resolutions, continued destruction of lives and properties, escalating internal and external refugee crisis and increasing Syria 
war related international terrorism are major implications of Russia and US involvement in Syria.

\section{RESEARCH METHOD}

This paper utilized the qualitative research method. In line with this, secondary sources of data collection such as documentary sources were relied upon, consequent upon this; the content analysis technique was employed for its data analysis.

\section{THEORETICAL FRAMEWORK}

In order to accurately appraise Russia and US involvement in Syria civil war, we adopted the theory of political realism (power model) as its framework of analysis. Though the theory has a long history being evident in Thucydides Peloponnesian war, it was influenced by Reinhold Niebuhr, Machiavelli the Prince, Thomas Hobbes and others but the theory had been expanded and modified by Hans Joachim Morgenthau (1904-1980). Thus in his books scientific man vs power politics and politics among nations, he developed the theory into a comprehensive international relations theory. The theory takes as its assumption that power defined as interest is the primary end that drives all political action in the international arena. Therefore, states will always seek to maximize power in order to survive.

\section{THE DRIVING FORCES BEHIND RUSSIA AND US INVOLVEMENT IN SYRIA CIVIL WAR.}

Stephen M. Watz (1996) affirms that revolution tend to open opportunities for states to improve their relative power positions, curb the positions of other states or do both. In the case of Syria, Russia and the US saw an opportunity to advance their interests as it concerns Syria and the middle east at large. Against this backdrop, we look at Russia and US principal policies in Syria.

\section{RUSSIA'S PRINCIPAL POLICIES IN SYRIA CIVIL WAR}

1. Maintaining Russia's nuclear deterrent capability as a guarantor of Russia's sovereignty and great power status: This is a major reason for Russia's involvement in Syria civil war. The Syria civil war laid bare the rare opportunity Russia has been strenuously seeking for to enhance, modernize, expand and maximize its military capabilities. In 2008, Russia's then prime minister (now president) Vladimir Putin lunched a massive military reform in order to strengthen Russia's military capabilities. The program's primary objective was to replace $70 \%$ of soviet era military hardware by the year 2020 (Dmitry, 2017). Prior to its military involvement in Syria, Russia had amended its naval doctrine, prioritizing confronting NATO's expansion and establishing its permanent fleet in the Mediterranean Sea and Atlantic Ocean (Bonder, 2015). in line with its military reform objectives, Russia's naval base in Tartus was upgraded after the intervention in 2015 from one that only provided basic maintenance to one that allows Russia ships passing through the Mediterranean into a permanent military deployment naval base (Bonder, 2015). Russia has also been using its military involvement in Syria as a testing ground for new weaponry, to improve its military capabilities. it has tested aircrafts that includes ship based cruise missiles, advance 400 surface to air defense system and Sukhoi Su-34 strike fighter, all of which have never been 
used in warfare before. Russia did not confine itself to the Tartus military base in Syria but rather constructed the large Hmeimim base in Latakia governorate to increase deployment in Syria (Gordon and Schmitt, 2015).

2. Denying competing powers or alliances the ability to dominate Russia's space: Other than preventing the growth of Sunni/Shia sectarianism, the need to curb the US agenda of regime change especially in countries friendly with Russia was uppermost to Russia (Dmitry, 2017). The Russia-Syria alliance is rooted in a very strong political and economic relationship that has served both countries well, since the 1950's. The friendship between these two countries rest upon their military cooperation, with Russia accounting for $90 \%$ of all Syrian's military imports in the 1970's. Russia defines the decision to sustain Assad's resistance as being ignited by "a world-wide conspiracy theory" led by the US, supporting movements to gain control and influence over the post-soviet space. Russia has maintained that the US should not exert any control or influence over the Syria opposition forces and views its attempt at removing an allied sitting government as deeply concerning (Gordon \& Schmitt, 2015). Allison assert that Assad and Putin have a shared outlook on territorial integrity and the rejection of "western regime change adventurism" as they are uncomfortable with the precedent such actions set especially in Libya (Allison, 2013). Thus, Russia uneasiness with allowing America influence in her backyard and the desire to curb NATO has resulted in its unwillingness to approve UN intervention in Syria.

3. Russia energy exports: Russia possesses a huge amount of bargaining power due to its control over energy flowing from its territory to Europe and other parts of the world. This has however been a problem to the West especially the US. The Islamic pipeline traversing the territories of Russia's allies which includes Syria serves Russia's national interests. The realization of another pipeline like Qatar's pipeline would decrease the West dependence on Russia gas exports of which Assad has played a considerable role in ensuring that Qatar's pipeline never traverses its territory because of its longstanding energy commitment to Russia. Therefore, the ousting of Assad by US will ensure a regime change that is favourable to the US and detrimental to Russia's hegemony on energy export and therefore unacceptable to Russia, hence the involvement (Williams, 2016).

\section{US PRINCIPAL POLICY IN SYRIA CIVIL WAR}

1. Preventing Terrorism and the use and spread of nuclear weapons: the 9/11 attack on US and its citizens encouraged the US to be extremely vigilant when it comes to issues of terrorist activities especially those that has the potential of reaching US territory. The civil war in Syria provided a breeding ground for the rapid growth of Sunni/Shia extremism in Syria. Worried for the safety of US citizens and its allies, the US decided that ISIS had to be defeated as quickly as possible and with minimum risk to their personnel, Hence the decision to equip the opposition in their fight against Syria related terrorism. To achieve this, the US choose the Kurdish democratic union party meaning PartiyaYekineyenDemokrat (PYD) in Kurdish and the peoples protection units meaning YekineyenParstina Gel (YPG) as its local allies in Syria and followed a policy to legitimatize it (Lund, 2015). Furthermore, on August 2011, the Obama's administration drew a 'Red Line' on the use of chemical weapons such as 
Sarin gas on its citizens, stating that any use of such weapon may result in military involvement from the US. However, following the allege use of chemical weapon by Assad government on its citizen, the US got involved by allowing the Central Intelligence Agency (CIA) to support the opposition with weapons, giving birth to Operation Sycamore (Mazzetti\&Younes, 2016).

2. Ensuring that the Middle East is not dominated by any power hostile to the US: It is no news that there exist, deteriorated relations between Damascus and Washington in the past years, owing to Syria's foreign policy towards Iran, its alleged possession of chemical weapons and support for Hezbollah. Backed by Lebanon's Hezbollah and Gaza's Hama clienteles, Iran's regional hegemony is based on Assad and Iraq Alawite regime in Syria. Therefore, the need to limit Iranian influence and its regional status in the Middle East triggered US involvement in Syria. Concerns about Iranian drones conducting overflight operations on US bases in Syria and Iraq has led to US air force shooting down Iranian UAVs on two occasions in 2017. US military assessments under the operation inherent resolve have specifically identified Iran as a state with hostile intent towards the US and its allies. Stating that, Iran's agenda in Syria includes maintaining the ability to strike Israel from Syria, retaining access to Hezbollah in Lebanon and securing security and economic contracts in Syria (lead inspector general for operation inherent resolve, 2019). In December 2019, following the death of a US contractor by Kata'ib Hezbollah(KH), the US launched a retaliatory airstrike on five pro-Iranian KB militias facilities (two in Eastern Syria and three in Iraq). Now, US personnel in Syria have become vulnerable to additional attacks by proIranian forces not just because of December 2019 retaliatory airstrikes but also as a result of the airstrike that killed Iranian Islamic Revolutionary Guard Corps-Qods Force(IRGC-QF), Commander QaseemSoleimani in January 2020 (Carla\& Christopher, 2020).

3. Ensuring energy security: The historical drive of US interests, particularly in the Middle East, centers on ensuring the free flow of its needed natural resources at very little or no cost. Accordingly, Eze (2015) argues that, contrary to US orchestrated 'democratization mission", and the likes, the quest to ensure steady access to the supply of her highly needed oil and at affordable prices is the main determinant of US foreign policies in the Middle East region. This is further buttressed by the fact that Although President Trump ordered the withdrawal of US forces from Syria, not all came back. The remnant forces stayed back to conduct operations and secure critical petroleum infrastructures in partnership with local opposition forces, against continuing terrorist threats emanating from Syria. In line with this, US vice president; Pence, stated that US troops in Syria will secure the oil fields so that they don't fall into the hands of the Assad regime, ISIS or Iran because US forces have the right to protect against any threat while securing the oil fields. However, Syrian officials have called for an end to what they refer to as the 'illegal' presence of US forces in Syria oil fields (CENTCOM,2020). Overtime, the warnings being issued by the Assad regime to the US forces might escalate into violent confrontations. President Trump inter alia stressed his position on the matter, stating that, "we may have to fight for the oil, it's okay. Maybe somebody else wants the oil, in which case they will have a hell of a fight" (Remarks by President Trump, 2019). 
The policy of the US in Syria is to support a UN sponsored political settlement that addresses the above objectives.

\section{DIPLOMATIC PROCESSES}

Since the beginning of the Syrian civil war, the Assad government and opposition have engaged in two major political negotiation platforms. These are the Geneva process and the Astana process. The Geneva process is a negotiation framework brokered by the UN, under the Geneva Communique framework endorsed by Russia and the US. The process which began in June 2012, calls for a transitional government but does not discuss the fate of Assad regime's regime. Consequent upon this, the opposition and Assad's government have adopted different perception to its meaning. For the opposition, negotiation begins with Assad out of power, while the Assad government insists that Assad was re-elected by referendum and that any form of settlement must begin by ending external involvement and striking at terrorism, which the government refer to as the opposition group (Syrian State News Agency, 2019).

The Astana process which can be described as a parallel track to the Geneva process is led by Russia and co-sponsored by Iran and Turkey. The processes began in January, 2017. Although not a sponsor, the US has been an observer of the process and has also been bellicose to the process replacing Geneva. Stating that the regime with the support of Russia wants to manipulate the process to their favour. These fears were substantiated in 2018 when most of the opposition groups boycotted the conference for Syrian people's congress" hosted by Russia in (New York times, 2018). The US have insisted that calls for political resolutions must follow the principles of the Geneva process but support from Russia has given Assad the incentive to disregard any UN's resolutions that would affect his regime.

\section{IMPLICATIONS OF RUSSIA AND US INVOLVEMENT IN SYRIA CIVIL WAR}

When there are multiple players as in Syria, it is extremely difficult to find an agreement that all veto players can agree upon and thus conflict drags on (David, 2013). The implication of the above statement has manifested greatly in Syria, resulting in an unending catastrophic war in the country. The protraction of the war in Syria is the most obvious consequence of Russia and US involvement in Syria. Although civil wars are accompanied by destructions, the level of these destructions are usually determined by the duration of the war. The longer the war, the more catastrophic it becomes and in this case, the protraction of the war in Syria has embodied in it, great negative outcomes which are discussed below:

\section{Destructions of Lives and Properties}

In September 2015, following its official invitation into the war by the Assad regime, Intensive raids were organized by the Russian armed forces which targeted rebels and the Islamic State. As a result, amid the absence of meaningful efforts to reduce abuses on Syrians or end the war, extreme violence escalated inside Syria. Many significant changes occurred on the front lines in Syria, and the initiative was taken by the Syrian Arab Army. Based on the Syrian Human Rights Watch data, by October 2015, the death toll exceeded 250,000 people including over 100,000 civilians and 3,153 members of rebel groups. 200 facilities of military significance had been destroyed, together with 
174 oil refineries and 111 oil convoys. More than 640,000 civilians live under long-term siege in Syria. The war has led to a humanitarian crisis with an estimated over 5.7 million Syrians in nearby countries registered under the United Nations High Commissioner for refugees while 6.2 million Syrians are internally displaced. ("Reliefweb", 2020) The scale and effects of the Russian involvement were also presented at the end of 2017 by Gen. Sergey Surovikin, the former Commander of the Russian Army in Syria. He claimed that in 227 days, over 32000 thousand terrorists were eliminated, 394 tanks destroyed, and $67000 \mathrm{~km}^{2}$ (square kilometers) of the Syrian territory liberated from the Islamic State group (Human Rights Watch, 2017). Even though Russia was able to liberate these territories from rebel forces, it came at a great price of human lives and of course the massive destruction of institutions and other landed properties that make up the Syrian state.

\section{The Economic Consequences of the War in Syria}

The war in Syria has also affected the Syrian economy and by extension, the Middle East region. The loss of lives and displacements seriously erodes human capital in Syria. The spreading of poverty in connection with warfare is significant and as employment declines, negative social consequences are disseminating even outside the directly involved geographic areas. The Syrian GDP has declined dramatically since the start of the war in 2011. Trade between Syria and its neighbors and even within the Middle East has reduced significantly. According to Phil de Imus et al (2017), key economic organizations and institutions attached to the Syrian economy have been hurt severely. For instance, buildings, facilities and infrastructure are damaged or destroyed. These can be production facilities relating to extraction of oil or natural gas, in other cases, roads, bridges, water supply facilities are becoming ruined or degraded. It is claimed that more than a quarter of the housing stock has been destroyed or damaged since the civil war started. The Syrian Centre for Policy Research has estimated that the costs of lost physical capital amount to $230 \%$ of the pre-war GDP. The last 9years pale in comparison to how much value the Syria pounds lost in 2020. This has resulted to increase in food prices, and high poverty rate. In May 2020, world food program recorded the highest level of food insecurity in Syria with over 9.3 million Syrians affected (Charles and Christopher, 2020).

\section{Syria's Refugee Crisis and Its Global Implications}

The repercussions of the degeneration of Syria's uprising into civil war have been felt strongly across the region, due to Syria's central location and geostrategic importance. It is important to reiterate that the civil war in Syria has displaced a vast number of Syrians from their homes and communities. The constantly rising number of Syrians fleeing the violence has put an enormous strain on neighboring countries. As the war continues to drag on, the neighboring countries are also bearing the brunt. By the end of April 2013, the United Nations registered more than 1.4 million refugees in the neighboring countries of Turkey, Lebanon, Jordan, Iraq and Egypt. Additionally, the Russian intervention also had a direct impact on the Syrian refugee crisis. In July 2015, i.e. before the commencement of Russia's full blown attacks, the number of refugees was estimated at 4 million. In October 2015, a significant increase in the number of Syrian residents fleeing the war zone was recorded. In January 2016, their number grew to 4.6 million, and it exceeded 5.5 million in September 2017. In all host countries, conflicts over the distribution of resources are likely to increase in proportion with the refugee influx and the burden is not cushioned effectively by the 
international community. Furthermore, the presence of Syrian refugees also increases tensions within the local population opening their boarders to accommodate them. The Syrian war has entangled militias and state actors across the region, destabilizing neighboring countries and stirring up ethnic tensions in Turkey, Lebanon and Iraq especially among the Sunni/shias and then the Kurds (Issa, 2016). Additionally, the current increase in migration to Europe is one of the most complexities facing the European Union today. For instance, the Russian air campaign in Syria creates dissonance between the US and Europe, especially with the unforeseen refugee crisis that has enveloped Europe. This, in turn, has increased the terrorist threat in broader Europe. Accordingly, Gen. Philip M. Breedlove, the former Supreme Allied Commander Europe, posit that Russian attacks on civilian targets, along with the use of chemical weapons and barrel bombs by the Assad regime, should be viewed as a strategy "weaponizing" the refugee crisis to destabilize Europe (Tisdall, 2017).

\section{The Use of Chemical Weapons in The Syrian War and its Implication on World Peace and Security}

According to a press statement released on 5th February 2018, by the U.S Department of state; "The United States of America is deeply concerned by the persistent allegations of the use of chlorine gas by the Syrian Regime to terrorize innocent civilians in the Idlib Province near Saraqib (Nauert, 2018). This attack is the sixth consecutive one in the past thirty days in Syria. One may not be too sure of proving Assad's innocence of using chemical weapons on rebel groups since the Assad government has denied such allegation but the perception of "the successful use of chemical weapons by Assad regime on its citizens without repercussion from the international community" definitely has an impact on the international community. For one, it will encourage other repressive governments to use the same cheap means of silencing agitations against their regime without fear of reprimand and it will also create fears in the mind of citizens nursing the ambition to protest against repressive government. Secondly, it can encourage states to acquire or produce such deadly weapons and stockpile for the purpose of using or threatening to use it on its enemies. These possible scenarios show huge prospects of threatening international peace and security. We urge the international community to speak with one voice, taking every opportunity to investigate without bias or prejudice and those found guilty, should be held accountable for such brutal attacks.

\section{The Problem of Syrian Related Global Terrorism}

The Syrian civil wars have been associated with the rise in practice of terrorist attack around its region. Schor, (2015) alludes that the persistent effect of terrorism in Syria is a direct result of Syria's civil war on the ground. In Syria, terrorism has been conveyed as a strategy by a portion of the dissident powers to realize a political, monetary, religious, and social objective of an Islamic caliphate. With the biggest terrorist groups in Syria(ISIL), most deaths from terrorism have been from bombings which are directly linked to this group. Since the transformation of the Syrian protest to civil war, Syria as a nation has been known to be the abode of terrorist groups associated with AlQaeda. The known activities of al-Qaeda in Syria war ostensibly changes the security circumstance of the region, with pledges to militaries both for the rebels and the Assad forces, thereby expanding violence over time. The Al-Nusrah Front and the Syrian Islamic State are representatives of alQaeda within Syria. The existence of this international network threatens the security of the international community (Schor, 2015). 


\section{Health Crisis}

With the help of Russia in the UN, the Assad government has long closed a lot of humanitarian aid across Syrian boarders that are outside the control of the regime. The closure has taken a toll on aids received for public health especially in this covid19 pandemic, prompting WHO to appeal to UN Security Council to re-open the affected boarders (Human right watch, 2020).

In addition to the above, as a consequence for Assad's refusal to adhere to the Geneva (UNSCR 2254) resolution, the US and its allies have threatened to;

I. Withhold reconstruction assistance

II. Block Syria's re-entry into the Arab league

III. Refusal to restore diplomatic relations with Damascus(New York Times, 2019)

\section{Summary}

1. Major impacts of the Syria war results from external involvements (Russia and the US) rather than Syria itself.

2. All diplomatic effort to foster peace have been hijacked and compromised by Russia and the US.

3. The Assad government has over the years become formidable due to Russia's unwavering support

\section{Findings}

The resurgence of Russia as a formidable challenger in the Middle East is diminishing US hegemony in the region and US reluctance to accept this new reality will continue to cripple Syria and the Middle East at large.

\section{Conclusion}

What happens when those charged with the decision to promote world peace dabble into proxy war with each other? Utter chaos. This has become the fate of Syrians as Russia and the US battle for stakes within the Syrian state. The inefficiency of the United Nations Organization has made it a viable tool, used by Russia and the US to diplomatically balance each other's power play in Syria. Unless there emerges a ground for compromise, or a clear dominant power, or an internationally recognized efficient bureaucracy, the unrest in Syria will drag on. 
International Journal of Advanced Academic Research (Social and Management Sciences) | ISSN: 2488-9849

Journal DOI: 10.46654/ij.24889849

Vol. 6, Issue 12 (December, 2020) | www.ijaar.org

Article DOI: 10.46654/ij.24889849.s61254

\section{References}

Allison, R. (2013), Russia and Syria: explaining alignment with a regime in crisis. International affairs, 89(4). retrieved from https://doi.org/10.1111/1468-2346.12046

Carla E.H \& Christopher M.B, (2020). 'Armed conflict in Syria: overview and US response'. Congressional research service. p44 available at http://crsreports.congress.govRL33487

Center for the Study of Civil War, (2010). Transnational Dimensions and the Myth of Civil Wars as National Events. Retrieved 5/10/2017 from http:www.prio.org>programmes

CENTCOM, (June 11, 2020). 'MEI engagement with general Kenneth F. Mckenzie Jr.' CENTCOM news transcript

David, E. C. (2013). Who Should Be at the Table? Veto Players and Peace Processes in Civil War. Penn State Journal of Law \& InternationalAffairs, 15 (2).

Dmitri, L. (2017). Russia Resolve: Why Syria Matters to Putin. The globe and mail, retrieved 26/04/2018 from www.theglobeandmail.com>world

Emadi, H. (2011). Requiem for the Baath Party: Struggle for Change and Freedom in Syria. Mediterranean Quarterly, 22(4), 62-79.

Eze, R.C. (2015). Oilas the Fundamental Determinant of United States Foreign Policy towards the Middle East.Arabian Journal of Business and Management Review. 5(3)

Gordon. M \& Schmitt, E. (2015, September 15).Russian Moves in Syria Widen Role in Mideast. New York. Retrieved 12/1/2018 from www.nytimes.com/2015/09/15/world/middleeast/russian-moves-insyriawiden-role-in-mideast.html.

Human Right Watch, (2017). Syria-events of 2017.Retrieved 2/3/2018 from http://www.hrw.org>countrychapters

Human right watch, (April 28, 2020). 'Syria: aid restrictions hinder covid-19 response'”

Issa, P. (2016, March 13). Syria Civil War: Five ways the conflict has changed the world. Retrieved from https://www.globalpolicy.org/globalization/defining-globalization/27662.

Lead Inspector General for Operation Inherent Resolve, (2019). Quarterly reports to the United States Congress, July 12019- October 25, 2019, p32

Lund, A. (2015, December 2).Syria's Kurds at the Center of America's Anti-Jihadi Strategy, Carnegie Endowment for International Peace, Retrieved 08-09-2017 from Carnegie-mec.org >diwan

Mazzetti, M. \&Younes, A. (2016, June 26).C.I.A. Arms for Syrian Rebels Supplied Black Market, Officials Say. New York Times. Retrieved 11/11/2017 fromhttps://www.nytimes.com/2016/06/27/world/middle east/cia-arms-for-syrian-rebels-supplied-black-market-officials-say.html

New York times, (January 30, 2018). 'Syrian peace talks in Russia: 1500delegates, mostly pro- Assad'.

New York times, (October 28, 2019).' Syrian peace talks to open after a long strange month'.

Nauert, H. (2018). Chemical Weapon Attack in Sarariq, Syria. Washington D.C: U.S Department of State.

Phil de Imus et al.(2017, December 17)"The Cost of Conflict. Middle East Strife Is Exacting a Heavy Toll on Regional Economies," Finance and Development.

Regan, P. M. (2000).Civil Wars and Foreign Powers. Ann Arbor, MI: University of Michigan Press.

Regan, P. M. (2002).Third Party Interventions and the Duration of Intrastate Conflict. Journal of Conflict Resolution, 46(1), 55-73.

Reliefweb, Syrian Arab republic. Latest figures available at http://m.reliefweb.int/country/226/syr?figuresdisplay=all.

Remarks by president trump on the death of ISIS leader Abu Bakr al-Baghdadi, October 7, 2019 
International Journal of Advanced Academic Research (Social and Management Sciences) | ISSN: 2488-9849

Journal DOI: 10.46654/ij.24889849

Vol. 6, Issue 12 (December, 2020) | www.ijaar.org

Article DOI: 10.46654/ij.24889849.s61254

Schor, C. (2015). The Global Terrorism Index: Measuring and Understanding the Impact on Terrorism. Institute for Economics and Peace.

Tisdall, S.(2018).Refugees are becoming Russia's weapon of choice in Syria, The Guardian. Retrieved I4/08/2018 from https://www.theguardian.com/world/2018/feb/16/refugees-are-becoming-russiasweapon-of-choice-in-syria

Syria state News Agency (October 31, 2019), interview of Syria president Assad by Syrian state Tv. Transcript by state news agency, available on Syria report.

William, F.E. (2016, September 17). "Russia Trumps USA Energy War in Mideast," New Eastern Outlook Retrieved 11/4/2019 from https://journal-neo.org/2016/09/17/russia-trumps-usa-energy-war-inmideast/; 